\title{
Prevalence of Tobacco mosaic virus in Iran and Evolutionary Analyses of the Coat Protein Gene
}

\author{
Athar Alishiri ${ }^{1}$, Farshad Rakhshandehroo ${ }^{*}$, Hamid-Reza Zamanizadeh ${ }^{1}$ and Peter Palukaitis ${ }^{2}$ \\ ${ }^{\prime}$ Department of Plant Pathology, College of Agriculture and Natural Resources, Science and Research Branch, Islamic Azad \\ University, Tehran 14515-775, Iran \\ ${ }^{2}$ Department of Horticultural Sciences, Seoul Women's University, Seoul 139-774, Korea \\ (Received on September 13, 2012; Revised on February 7, 2013; Accepted on March 5, 2013)
}

\begin{abstract}
The incidence and distribution of Tobacco mosaic virus (TMV) and related tobamoviruses was determined using an enzyme-linked immunosorbent assay on 1,926 symptomatic horticultural crops and 107 asymptomatic weed samples collected from 78 highly infected fields in the major horticultural crop-producing areas in 17 provinces throughout Iran. The results were confirmed by host range studies and reverse transcription-polymerase chain reaction. The overall incidence of infection by these viruses in symptomatic plants was $11.3 \%$. The coat protein (CP) gene sequences of a number of isolates were determined and disclosed to be a high identity (up to $100 \%$ ) among the Iranian isolates. Phylogenetic analysis of all known TMV CP genes showed three clades on the basis of nucleotide sequences with all Iranian isolates distinctly clustered in clade II. Analysis using the complete CP amino acid sequence showed one clade with two subgroups, IA and IB, with Iranian isolates in both subgroups. The nucleotide diversity within each subgroup was very low, but higher between the two clades. No correlation was found between genetic distance and geographical origin or host species of isolation. Statistical analyses suggested a negative selection and demonstrated the occurrence of gene flow from the isolates in other clades to the Iranian population.
\end{abstract}

Keywords : coat protein, gene flow, phylogeny, TMV, Tobamovirus

Iran, with an area of 1.65 million square kilometres, contains several different types of climate. Horticultural crop farming is carried out in most of the geographical regions in Iran, except for the deserts and mountains. The climate of Iran is conducive to the growing of many horticultural crops such as broad beans (Vicia faba L.), carrots (Daucus carota subsp. sativus), varieties of cucurbit plants [including

\footnotetext{
*Corresponding author.

Phone) +989124786687, FAX) +982144865464

E-mail) rakhshandehroo_fa@srbiau.ac.ir
}

cantaloupe (Cucumis melo var. cantalupensis), courgettes (Cucurbita pepo L. cv. Zucchini), cucumber (Cucumis sativus L.), melon (C. melo L.), pumpkin (Cucurbita moschata Duch.), watermelon (Citrullus lanatus var. lanatus) and winter squash (Cucurbita maxima Duch. ex Lam)], eggplant (Solanum melongena L.), garlic (Allium sativum L.), green beans (Phaseolus vulgaris L.), onion (Allium cepa L.), pepper (Capsicum annum L.), potato (Solanum tuberosum subsp. tuberosum), spinach (Spinacia oleraceae L.) and tomato (Solanum lycopersicum L.). Such crop production in the field may be either rain-fed or under irrigation on large scale or small holder commercial farms. Iran is among the main producers of horticulural crops in the world with an approximate production of 1,800,400 tonnes yearly (Faostat, 2009). Cucurbits and tomato are major horticultural crops in Iran (Faostat, 2009). Viral diseases of horticultural crops cause important economic impact worldwide. Among all other viral diseases of such crops, diseases caused by tobamoviruses are often the most destructive and difficult to control (Alonso et al., 1989).

On the basis of genome organization and phylogenetic clustering, tobamoviruses are classified into three subgroups (Lartey et al., 1996). Tobamoviruses in subgroup 1, including Tobacco mosaic virus (TMV), Tomato mosaic virus (ToMV), Pepper mild mottle virus (PMMV) and Tobacco mild green mosaic virus (TMGMV), are known to infect mostly solanaceous plants. Several tobamoviruses that previously were considered as TMV strains, are now classified as members of new species of the genus Tobamovirus on the basis of differences in host range, serological properties and amino acid sequences of encoded virus proteins (Antignus et al., 2001; Wang et al., 1997). TMV is the type member of the genus Tobamovirus. The TMV virion is a rigid rod $(18 \mathrm{~nm} \times 300 \mathrm{~nm})$ containing a singlestranded, positive-sense RNA (Zaitlin, 1999). TMV can be transmitted by mechanical inoculation, grafting, contact between plants and by seed, but not by any known vector (Broadbent, 1965; Hollings and Huttinga, 1976). Tobamoviruses collectively have a very wide host range and cause 
serious economic impact and significantly yield losses in many crops such as brassicas, cucurbits, solanaceous crops and different ornamental plants such as chrysanthemums (Chrysanthemum indicum L.), impatiens (Impatiens balsamina) and petunia (Petunia $\times$ hybrida) (Alexandre et al., 2000; Choi et al., 2009; Kumar et al., 2011; Nassar et al., 2012). Infected plants often show different types of symptoms such as malformations, mosaic and stunting on leaves, flowers, and fruit. TMV has been reported to cause considerable reduction in the tonnage of tomato fruit up to 59\% (Cherian and Muniyapppa, 1998). Significant yield losses of about $90 \%$ due to TMV infection in pepper also have been reported (Chitra et al., 2002). There are many different strains identified for TMV, some of which are capable of overcoming of their hosts resistance (Padgett and Beachy, 1993). Regardless of the importance of fieldgrown horticultural crops, there is little information available on the incidence and distribution of TMV and its genetic diversity in cultivated crops in Iran. Thus, in this study we determined the incidence of TMV in plants showing symptoms in commercial fields in the main important provinces for horticultural crop cultivation in Iran, and also determined the genetic diversity of the isolates detected in the surveyed regions. We also detected TMV in some weed species growing in and around crop fields which may be potential reservoir hosts for maintaining TMV in these fields. The information obtained is required as the first step toward the search for control strategies of virus diseases in horticulural crops in Iran.

\section{Materials and Methods}

Surveys and sample collection. Samples of horticultural crop species including bean, cabbage (Brassica oleracea var. capitata), cucumber, eggplant, pepper, potato, pumpkin, radish (Raphanus sativus), tomato, watermelon, and zucchini. were collected from April 2009 to May 2010 from open fields in the following 17 provinces (and specified districts) of Iran: Alburz (Karaj), Boushehr (Boushehr), East Azarbaijan (Maragheh), Fras (Darab, Fasa, Jahrum and Larestan), Golestan (Minoodasht), Hamedan (Tuyserkan), Hormozgan (Hajiabad, Kehorestan, Minab, Roudan), Isfahan (Isfahan), Kerman (Jiroft), Kermanshah (Mahidasht), Khuzestan (Dezful), Mazandaran (Noshahr), Qazvin (Qazvin), Qom (Qom), Sistan and Baluchestan (Zabul and Zahedan), Tehran (Tehran, Varamin, Shahriar), and West Azarbaijan (Urmia) (Table 1). Overall, 78 fields were surveyed and 1926 samples (20-30 samples per field) were collected during the growing season. The fields were randomly selected using a predetermined distance criterion, where distance between the fields ranged from 10 to $30 \mathrm{~km}$. A sample consisted of two symptomatic leaves per plant. Viral-like symptoms observed included dwarfing, mosaic, mottling, yellowing, leaf malformation, necrosis of the leaves and stems and vein clearing. In addition, 107 leaf samples were also collected from different asymptomatic weed species belonging to 12 different botanical families within visited horticultural crop fields in the surveyed provinces for the serological detection of TMV and related tobamoviruses (Table 2). Weed samples were collected from around the bases of crops showing symptoms characteristic of infection by TMV.

Virus testing. Mature leaf blades were tested in duplicate using double antibody sandwich enzyme-linked immunosorbent assay (DAS-ELISA), with coating antibodies against TMV and related tobamoviruses, as well as alkaline phosphatase conjugates obtained from Agdia (Agdia, Inc., South Bend, IN, USA) (Clark and Adams, 1977).

Host range. Leaf samples showing symptoms associated with virus disease and with positive reaction in ELISA that were collected from Alburz, East Azarbaijan, Fars, Golestan and Tehran provinces, which contain the main horticultural crop cultivation regions of Iran, were selected and further evaluated in a host range study. The virus isolates were purified biologically through a single local lesion technique repeated twice on Chenopodium quinoa plants, and then transmitted mechanically to Nicotiana tabacum cv. White Burley for virus propagation according to the published protocol (Adkins et al., 2003). Extracts from the systemically-infected tobacco plants were then used as a source of biologically-purified virus and inoculated mechanically to $C$. quinoa (family Chenopodiaceae), C. sativus (cucumber; family Cucurbitaceae), Vigna unguiculata cv. Mashhad (cowpea) and Vicia faba (faba bean; family Fabaceae), N. rustica, N. tabacum cv Samsun nn, N. tabacum cv. Virginia, N. tabacum cv. White Burley and S. lycopersicum (tomato), Petunia hybrida (all in the family Solanaceae). (Table 3). Specifically, $1 \mathrm{~g}$ of leaf tissue was ground in $2 \mathrm{ml}$ of $0.1 \mathrm{M}$ potassium phosphate buffer, $\mathrm{pH}$ 7.5. The extract was rubbed onto leaves of the above herbaceous plants, previously dusted with 300-mesh Carborundum. The experiment was conducted twice using at least three plants for each inoculation. The inoculated plants were then transferred to a greenhouse and maintained at 20 to $30^{\circ} \mathrm{C}$ with 12 to $14 \mathrm{~h}$ natural lighting for the duration of the test. The final symptom reading was conducted 4 weeks post inoculation, and systemic leaf tissues from each individual plant were collected to confirm the presence of virus by ELISA. The presence of the virus in asymptomatic plants was verified by reverse transcription-polymerase chain reaction (RT-PCR).

RT-PCR and sequencing analyses. Total RNA extraction 
Table 1. Incidence of tobamoviruses on horticultural crops collected from the main provinces of cultivation in Iran

\begin{tabular}{|c|c|c|c|c|c|c|c|c|c|c|c|c|c|}
\hline \multicolumn{14}{|c|}{ Sampled horticultural crops ${ }^{\mathrm{a}}$} \\
\hline \multirow[b]{2}{*}{ Province } & \multirow[b]{2}{*}{ Region } & \multirow[b]{2}{*}{$\begin{array}{l}\text { Infected } \\
\text { Samples }^{\text {b }}\end{array}$} & \multicolumn{4}{|c|}{ Solanaceous } & \multicolumn{4}{|c|}{ Cucurbitaceous } & \multirow{2}{*}{$\frac{\text { Legumes }}{\text { Bean }}$} & \multicolumn{2}{|c|}{ Brassicas } \\
\hline & & & Tomato & Potato & $\begin{array}{l}\text { Egg- } \\
\text { plant }\end{array}$ & Pepper & $\begin{array}{l}\text { Cucum- } \\
\text { ber }\end{array}$ & $\begin{array}{l}\text { Water- } \\
\text { melon }\end{array}$ & $\begin{array}{l}\text { Zuc- } \\
\text { chini }\end{array}$ & $\begin{array}{l}\text { Pump- } \\
\text { kin }\end{array}$ & & Radish & Cabbage \\
\hline \multirow[t]{4}{*}{ Fars } & Larestan & $0 / 69$ & $0 / 32$ & $0 / 3$ & $0 / 9$ & $0 / 1$ & $0 / 6$ & ND & $0 / 3$ & $0 / 2$ & $0 / 8$ & ND & $0 / 5$ \\
\hline & Fasa & $11 / 92$ & $1 / 4$ & $\mathbf{9 / 5 7}$ & $0 / 2$ & $1 / 5$ & ND & $0 / 5$ & $0 / 4$ & $0 / 6$ & $0 / 2$ & $0 / 4$ & $0 / 3$ \\
\hline & Jahrum & $3 / 63$ & $3 / 42$ & ND & ND & $0 / 14$ & ND & $0 / 4$ & ND & ND & $0 / 3$ & ND & ND \\
\hline & Darab & $\begin{array}{c}36 / 215 \\
(11.38 \%)^{c}\end{array}$ & $36 / 100$ & $0 / 17$ & $0 / 15$ & ND & $0 / 30$ & $0 / 1$ & $0 / 8$ & ND & $0 / 30$ & $0 / 2$ & $0 / 12$ \\
\hline Isfahan & Isfahan & $\begin{array}{c}1 / 65 \\
(1.5 \%)\end{array}$ & $1 / 47$ & ND & $0 / 3$ & ND & $0 / 5$ & $0 / 2$ & $0 / 2$ & $0 / 3$ & $0 / 3$ & ND & ND \\
\hline Sistan and & Zabul & $0 / 29$ & $0 / 10$ & ND & ND & ND & $0 / 3$ & $0 / 3$ & $0 / 3$ & $0 / 3$ & $0 / 2$ & $0 / 4$ & $0 / 1$ \\
\hline Baluchestan & Zahedan & $\begin{array}{c}3 / 28 \\
(5.2 \%)\end{array}$ & $0 / 15$ & ND & ND & $2 / 5$ & $1 / 1$ & ND & $0 / 2$ & $0 / 5$ & ND & ND & ND \\
\hline Alburz & Karaj & $\begin{array}{c}12 / 72 \\
(16.6 \%)\end{array}$ & $3 / 10$ & $1 / 6$ & $3 / 9$ & $2 / 9$ & ND & $0 / 6$ & $1 / 9$ & $2 / 7$ & $0 / 5$ & $0 / 8$ & $0 / 3$ \\
\hline $\begin{array}{c}\text { East } \\
\text { Azarbaijan }\end{array}$ & Maragheh & $\begin{array}{c}12 / 128 \\
(9.37 \%)\end{array}$ & $6 / 64$ & ND & $1 / 9$ & ND & $3 / 40$ & ND & $1 / 1$ & $1 / 1$ & $0 / 4$ & $0 / 5$ & $0 / 4$ \\
\hline Mazandaran & Noshahr & $\begin{array}{c}2 / 62 \\
(3.22 \%)\end{array}$ & ND & ND & $0 / 13$ & $1 / 20$ & ND & ND & ND & $1 / 12$ & $0 / 6$ & $0 / 7$ & $0 / 4$ \\
\hline Golestan & minoodasht & $\begin{array}{l}34 / 79 \\
(43 \%)\end{array}$ & $14 / 23$ & ND & $8 / 16$ & ND & $0 / 2$ & $2 / 10$ & $4 / 18$ & ND & $6 / 8$ & ND & $0 / 2$ \\
\hline Boushehr & Boushehr & $\begin{array}{c}1 / 57 \\
(1.75 \%)\end{array}$ & $0 / 30$ & ND & ND & $1 / 5$ & ND & $0 / 4$ & $0 / 3$ & $0 / 4$ & ND & $0 / 3$ & $0 / 8$ \\
\hline $\begin{array}{c}\text { West } \\
\text { Azarbaijan }\end{array}$ & Urmia & $\begin{array}{c}20 / 107 \\
(18.7 \%)\end{array}$ & $5 / 15$ & ND & $1 / 7$ & $2 / 9$ & $0 / 32$ & $9 / 34$ & $0 / 1$ & ND & ND & ND & $3 / 9$ \\
\hline Qazvin & Qazvin & $\begin{array}{l}0 / 35 \\
(0 \%)\end{array}$ & $0 / 4$ & $0 / 8$ & $0 / 2$ & ND & $0 / 5$ & ND & $0 / 4$ & ND & $0 / 3$ & $0 / 4$ & $0 / 5$ \\
\hline \multirow{3}{*}{ Tehran } & Tehran & $39 / 110$ & $39 / 77$ & ND & $0 / 15$ & $0 / 4$ & ND & $0 / 6$ & ND & $0 / 5$ & ND & $0 / 3$ & ND \\
\hline & Varamin & $21 / 158$ & $4 / 35$ & ND & $8 / 45$ & $0 / 2$ & $0 / 19$ & $0 / 3$ & $7 / 42$ & $0 / 4$ & $0 / 1$ & ND & $2 / 7$ \\
\hline & Shahriar & $\begin{array}{c}2 / 33 \\
(20.6 \%)\end{array}$ & $2 / 17$ & ND & ND & ND & ND & $0 / 4$ & ND & ND & $0 / 5$ & $0 / 4$ & $0 / 3$ \\
\hline Qom & Qom & $\begin{array}{c}7 / 57 \\
(12.3 \%)\end{array}$ & $1 / 11$ & ND & $4 / 13$ & $1 / 13$ & $0 / 9$ & $0 / 3$ & ND & $1 / 6$ & ND & ND & $0 / 2$ \\
\hline Kerman & Jiroft & $\begin{array}{l}2 / 65 \\
(3 \%)\end{array}$ & $0 / 22$ & $0 / 6$ & ND & $0 / 5$ & $0 / 9$ & $1 / 8$ & ND & $1 / 9$ & $0 / 6$ & ND & ND \\
\hline Khuzestan & Dezful & $\begin{array}{l}0 / 68 \\
(0 \%)\end{array}$ & $0 / 54$ & ND & ND & ND & $0 / 3$ & ND & $0 / 2$ & ND & ND & $0 / 3$ & $0 / 6$ \\
\hline \multirow{4}{*}{ Hormozgan } & Roudan & $3 / 83$ & $0 / 25$ & ND & $2 / 19$ & $0 / 10$ & $1 / 9$ & $0 / 5$ & ND & ND & $0 / 8$ & ND & $0 / 7$ \\
\hline & Minab & $0 / 29$ & ND & ND & $0 / 3$ & $0 / 5$ & $0 / 2$ & $0 / 4$ & ND & $0 / 7$ & $0 / 2$ & $0 / 6$ & ND \\
\hline & Kehorestan & $2 / 70$ & $1 / 40$ & ND & $0 / 1$ & $1 / 8$ & $0 / 4$ & ND & $0 / 7$ & $0 / 3$ & $0 / 7$ & ND & ND \\
\hline & Hajiabad & $\begin{array}{c}3 / 66 \\
(3.2 \%)\end{array}$ & ND & $1 / 40$ & ND & $1 / 10$ & $0 / 3$ & $1 / 2$ & $0 / 4$ & $0 / 3$ & $0 / 4$ & ND & ND \\
\hline Hamedan & Tuyserkan & $\begin{array}{c}3 / 40 \\
(7.5 \%)\end{array}$ & $2 / 8$ & $1 / 9$ & ND & ND & $0 / 5$ & ND & ND & $0 / 2$ & $0 / 8$ & $0 / 6$ & $0 / 2$ \\
\hline Kermanshah & Mahidasht & $\begin{array}{c}1 / 46 \\
(2.1 \%)\end{array}$ & $0 / 14$ & ND & $0 / 8$ & $1 / 8$ & ND & $0 / 4$ & $0 / 5$ & $0 / 4$ & $0 / 3$ & ND & ND \\
\hline Total & & $\begin{array}{c}218 / 1926 \\
(11.3)^{\mathrm{d}}\end{array}$ & $\begin{array}{c}118 / 699 \\
(\mathbf{1 6 . 9})^{\mathrm{e}}\end{array}$ & $\begin{array}{c}12 / 146 \\
(8.2)\end{array}$ & $\begin{array}{c}27 / 189 \\
(14.2)\end{array}$ & $\begin{array}{c}13 / 133 \\
(9.7)\end{array}$ & $\begin{array}{l}5 / 187 \\
(2.6)\end{array}$ & $\begin{array}{c}13 / 108 \\
(12)\end{array}$ & $\begin{array}{c}13 / 118 \\
(11)\end{array}$ & $\begin{array}{l}6 / 86 \\
(6.9)\end{array}$ & $\begin{array}{c}6 / 118 \\
(5)\end{array}$ & $\begin{array}{c}0 / 59 \\
(0)\end{array}$ & $\begin{array}{c}5 / 83 \\
(6)\end{array}$ \\
\hline
\end{tabular}

The highest incidence for tobamovirus infection in each surveyed host species is shown in bold and was highest for tomato.

${ }^{a}$ Data obtained by DAS-ELISA for tobamovirus. Number of infected samples over number of samples collected for each crop. ND $=$ not determined.

${ }^{\mathrm{b}}$ Nunber of infected samples over number of samples collected for each province.

${ }^{c}$ Percentage of tobamovirus infection in each province.

${ }^{\mathrm{d}}$ Average percentage of tobamovirus infection for all provinces.

${ }^{\mathrm{e}}$ Average percentage of tobamovirus infection in each crop species. 
Table 2. Incidence of tobamovirus infection on selected weed species

\begin{tabular}{|c|c|c|}
\hline $\begin{array}{l}\text { Family } \\
\text { species }\end{array}$ & Common name & Incidence $^{a}$ \\
\hline Chenopodiaceae & & $(23.3 \%)$ \\
\hline Chenopodium murale L. & Nettle-Leaf goosefoot & $5 / 17^{\mathrm{b}}$ \\
\hline C. album $\mathrm{L}$. & Lamb's quarters & $2 / 7$ \\
\hline C. amaranticolor $\mathrm{L}$. & Goosefoot & $0 / 3$ \\
\hline Salsola kali L. & Saltwort & $0 / 3$ \\
\hline Malvaceae & & $(9 \%)$ \\
\hline Malva neglecta Wallr. & Common mallow & $1 / 11$ \\
\hline Portulacaceae & & $(0)$ \\
\hline Portulaca oleraceae L. & Common Purslane & $0 / 5$ \\
\hline Solanaceae & & $(0)$ \\
\hline Solanum nigrum L. & Nightshade & $0 / 4$ \\
\hline Physalis alkekengi L. & Bladder cherry & $0 / 3$ \\
\hline Convolvulaceae & & $(11.1 \%)$ \\
\hline Convolvulus arvensis L. & Field Bindweed & $1 / 6$ \\
\hline Calystegia sepium L. & Hedge Bindweed & $0 / 3$ \\
\hline Orobanchaceae & & $(0)$ \\
\hline Orobanche aegyptica Pers. & Broomrape & $0 / 3$ \\
\hline Polygonaceae & & $(0)$ \\
\hline Rumex vesicarius L. & Bladderdock & $0 / 3$ \\
\hline Polygonum aviculare L. & Knotweed & $0 / 2$ \\
\hline Asteraceae & & $(20 \%)$ \\
\hline Sonchus oleraceus L & Sowthistle & $1 / 3$ \\
\hline Cirsium arvensis $\mathrm{L}$. & Canada thistle & $1 / 5$ \\
\hline Lactuca scariola L. & Prickly Lettuce & $0 / 2$ \\
\hline Amaranthaceae & & $(0)$ \\
\hline Amaranthus retroflexus L. & Redroot pigweed & $0 / 3$ \\
\hline Amaranthus hybridus L. & Slim amaranthus & $0 / 3$ \\
\hline Spinacia oleracea L. & Garden spinach & $0 / 3$ \\
\hline Brassicaceae & & $(0)$ \\
\hline Raohanus raphanistrum L. & Wild radish & $0 / 3$ \\
\hline Sinaps arvensis L. & Wild mustard & $0 / 3$ \\
\hline Fabaceae & & $(11.1 \%)$ \\
\hline Glycyrrhiza glabra L. & Licorice root & $0 / 3$ \\
\hline Trigonella persica $\mathrm{L}$. & Fenugreek & $1 / 3$ \\
\hline Ononis spinosa $\mathrm{L}$. & Spiny rest harrow & $0 / 3$ \\
\hline Boraginaceae & & $(0)$ \\
\hline Heliotropium europium L. & European heliotrope & $0 / 3$ \\
\hline Total & & $\begin{array}{c}12 / 107 \\
(11.2 \%)^{\mathrm{c}}\end{array}$ \\
\hline
\end{tabular}

${ }^{a}$ Incidence rate of tobamovirus infection on different weed families in the surveyed provinces from Table 1.

${ }^{\mathrm{b}}$ No. of infected samples/collected samples, determined by DASELISA detection of tobamoviruses infecting different weed species collected from surveyed vegetable fields.

${ }^{c}$ Average incidence of tobamovirus infection on selected weed species.

was performed using $\mathrm{LiCl}$ buffer according to the protocol described by Channuntapipat et al. (2001). Total RNAs were isolated from leaves of symptomatic crop plants, asymptomatic weed species and indicator plants (N. rustica) inoculated with selected Iranian TMV isolates including isolates TA, TV, TM, G42 and PU1. First-strand cDNA synthesis was carried out according to the manufacturer's instructions (MBI, Fermentas, Germany) in a $20 \mu 1$ reaction containing $10 \mathrm{ng}$ of total RNA, 20 pmol reverse primers (Tob-Uni-1), $50 \mathrm{mM}$ Tris-HCl, $\mathrm{pH} 8.3,50 \mathrm{mM} \mathrm{KCl,} 10$ $\mathrm{mM}$ of each of the four dNTPs, $20 \mathrm{mM}$ DTT, 20 U Ribonuclease inhibitor and 200 U M-MuLV Reverse transcriptase (MBI, Fermentas, Germany). RT-PCR was carried out with specific degenerate primers designed by Letschert et al. (2002). Degenerate primers Tob-Uni 1 (5'-ATTTAAGT GGASGGAAAAVCACT-3') and Tob-Uni 2 (5'-GTYGTT GATGAGTTCRTGGA-3') were used for the genus-specific detection of tobamoviruses that were detected serologically using a specific polyclonal antibody in DAS-ELISA. Specific detection of tobamoviruses species was also performed with a semi-nested PCR method according to Letschert et al. (2002) using Tob-Uni-1 as the downstream primer and TMV-spec (5'-CGGTCAGTGCCGAACAAGAA3'), ToMV-spec (5'-CGGAA-GGCCTAAACCAAAAAG$3^{\prime}$ ), and TMGMV-spec (5'-AARTAAATAAYAGTGGTAA GAAGGG-3') forward primers for amplifying the coat protein $(\mathrm{CP})$ gene of TMV, ToMV and TMGMV respectively. The primers were synthesized by MWG Biotech (Germany). The amplified fragment was expected to be $c a .690 \mathrm{bp}, 694$ bp and $720 \mathrm{bp}$ for TMV, ToMV and TMGMV, respectively, which encompasses $480 \mathrm{bp}$ of the $\mathrm{CP}$ coding region plus sequences of the 5 ' and $3^{\prime}$ flanking regions. Amplification was carried out in a thermocycler (Eppendorf, Hamburg, Germany) using initial denaturation at $94{ }^{\circ} \mathrm{C}$ for $5 \mathrm{~min}$ followed by 30 cycles at $94^{\circ} \mathrm{C}$ for $60 \mathrm{~s}, 60^{\circ} \mathrm{C}$ for $45 \mathrm{~s}$, $72{ }^{\circ} \mathrm{C}$ elongation for $60 \mathrm{~s}$, and a final extension step at $72{ }^{\circ} \mathrm{C}$ for $5 \mathrm{~min}$. The PCR mixture (final volume of $25 \mu \mathrm{l}$ ) contained $2.5 \mu \mathrm{l}$ of cDNA, $2 \mathrm{mM} \mathrm{MgCl}, 0.2 \mathrm{mM}$ of each dNTP, $0.4 \mu \mathrm{M}$ of each primer, and $2.5 \mathrm{U}$ of Taq DNA polymerase (Cinnagene, Iran) in the buffer recommended by the manufacturer. PCR products were checked on gels of $1.5 \%$ agarose in $0.5 \times$ TBE buffer $(45 \mathrm{mM}$ Tris-borate, 1 mM EDTA, pH 8.0). containing ethidium bromide.

The TMV amplicons (CP gene) for different isolates were obtained from the agarose gels, puried using an UltraClean purification kit as described by the manufacturer (Fermentas Gene JET TM Gel Extraction Kit, Germany), and subjected to dideoxyterminator cycle sequencing by Macrogen (Seoul, South Korea). At least two clones of the $\mathrm{CP}$ gene of each TMV isolate were selected and sequenced. The sequences obtained were compared with virus sequences available in the GenBank database using BLAST (Altschul et al., 1997). Phylogenetic analysis of the five representative Iranian TMV isolates was conducted by 
Table 3. Symptom development on indicator plant species after inoculation with Tobacco mosaic virus (TMV) isolates detected in Iran

\begin{tabular}{|c|c|c|c|c|c|c|}
\hline \multirow[b]{2}{*}{ Indicator plant } & \multirow[b]{2}{*}{$\mathrm{U} 1^{\mathrm{b}}$} & \multicolumn{5}{|c|}{ Leaf symptoms caused by TMV pathological clusters ${ }^{\mathrm{a}}$} \\
\hline & & TA & TV & G42 & PU1 & $\mathrm{TM}$ \\
\hline \multicolumn{7}{|l|}{ Solanaceae } \\
\hline Nicotiana rustica & $\mathrm{NL} /-^{\mathrm{c}}$ & $\mathrm{NL} /-$ & $\mathrm{NL} /-$ & $\mathrm{NL} /-$ & $\mathrm{NL} /-$ & $\mathrm{NL} /-$ \\
\hline N. tabacum cv. Samsun nn & $-/ \mathrm{M}$ & $-/ \mathrm{M}$, Def & NL/M & $-/ \mathrm{M}$ & $-/ \mathrm{M}$ & $-/ \mathrm{M}$ \\
\hline N. tabacum cv. Virginia & $\mathrm{NL}, \mathrm{M} /-$ & $\mathrm{NL}, \mathrm{M} /-$ & NL, M/- & $\mathrm{NL}, \mathrm{M} /-$ & $\mathrm{NL}, \mathrm{M} / \mathrm{VC}$ & $\mathrm{NL}, \mathrm{M} /-$ \\
\hline N. tabacum cv. White burley & $-/ \mathrm{VC}$ & $-/ \mathrm{VC}$ & $-/ \mathrm{VC}$ & $-/ \mathrm{VC}$ & $-/ \mathrm{VC}$ & $-/ \mathrm{VC}$ \\
\hline Solanum lycopersicum & $\mathrm{M} / \mathrm{LC}$ & $\mathrm{M} / \mathrm{LC}$ & $-/ \mathrm{LC}$ & $\mathrm{M} / \mathrm{LC}$ & $\mathrm{M} /-$ & $\mathrm{M} /-$ \\
\hline Petunia hybrida & $-/ \mathrm{M}$ & $-/ \mathrm{M}$ & $-/ \mathrm{M}$ & $-/ \mathrm{M}$ & $\mathrm{NL} / \mathrm{M}$ & $-/ \mathrm{M}$ \\
\hline \multicolumn{7}{|l|}{ Chenopodiaceae } \\
\hline Chenopodium quinoa & $\mathrm{CL} /-$ & $\mathrm{CL} /-$ & $\mathrm{CL} /-$ & $\mathrm{CL} /-$ & $\mathrm{CL} / \mathrm{LC}$ & $\mathrm{NL} /-$ \\
\hline \multicolumn{7}{|l|}{ Cucurbitaceae } \\
\hline Cucumis sativus & $-1-$ & $-1-$ & $-1-$ & $-1-$ & $--^{\mathrm{d}}$ & $-1-$ \\
\hline \multicolumn{7}{|l|}{ Fabaceae } \\
\hline Vigna unguiculata $\mathrm{cv}$. Mashhad & $-1-$ & $-/-$ & $-/-$ & $-/-$ & IVC/- & $-1-$ \\
\hline Vicia faba & $\mathrm{NL} /-$ & $\mathrm{NL} /-$ & $\mathrm{NL} /-$ & $\mathrm{NL} /-$ & $\mathrm{NL} /-$ & $\mathrm{NL} /-$ \\
\hline
\end{tabular}

${ }^{\mathrm{a}}$ Abbreviations: CL, cholorotic local lesions; Def, deformation; IVC, interveinal chlorosis; LC, leaf curling; NL, necrotic local lesions; VC, vein clearing; M, mosaic; - , no symptoms.

${ }^{\mathrm{b}}$ TMV common strain U1 from the Cornell University, Plant Virus collection.

${ }^{\mathrm{c}}$ Local symptoms/systemic symptoms.

${ }^{\mathrm{d}}$ The inoculated plants remain symptomless but virus was detectable by ELISA and PCR.

comparing separately the 480 nucleotides (nt) of the whole $\mathrm{CP}$ gene and the $161 \mathrm{nt}$ that included the flanking regions of the CP-coding region with the comparable sequences of other TMV isolates from GenBank. Multiple nucleotide sequence alignments of the Iranian isolates with the previously reported TMV isolates were performed using CLUSTALX 1.8 (Pearson and Lipman, 1988). Phylogenetic relationships were inferred by using the Maximum Likelihood method based on the Kimura 2-parameter model with 1000 bootstraps replicates to estimate node significances (Kimura, 1980), using a CP gene sequence of Odontoglossum ringspot virus (ORSV) as an outgroup. This comparison extended to deduced amino acid sequences. Analyses were performed with the program MEGA 5.05 (Tamura et al., 2011). Using this software and the Tamura3-parameter nucleotide substitution model (Tamura, 1992), the nucleotide distances and diversities were assessed. Genetic differentiation and the gene flow level between subpopulations also were evaluated by the statistical test $\mathrm{F}_{\text {st }}$ (Weir and Cockerham, 1984). $F_{\text {st }}$ ranges from 0 to 1 for undifferentiated to fully differentiated populations, respectively. The statistical tests for estimation of $\mathrm{F}_{\mathrm{st}}$ were performed by DnaSP version 5.10.01 (Librado and Rozas, 2009). The ratio of non-synonymous nucleotide diversity to synonymous nucleotide diversity [Pi(a)/Pi(s)] was estimated by the use of DnaSP version 5.10.01 for the Iranian TMV isolates. The value of this ratio is $1,<1$ and $>1$ under neutral, negative (purifying selection) and positive (direc- tional selection), respectively.

\section{Results}

Field survey and incidence of tobamovirus infection in symptomatic horticultural crops. Of 1,926 crop leaf samples showing symptoms that were tested by ELISA, tobamoviruses were found in 218 samples ( $11.3 \%$ incidence). The results showed that 53 out of 78 fields surveyed had tobamovirus infections, ranging from 1.5 to $43 \%$ of the plants showing symptoms. Apart from Qazvin and Khuzestan provinces, tobamoviruses were distributed among the fifteen surveyed provinces with higher and lower disease incidence in Golestan and Isfahan provinces respectively (Fig. 1, Table 1). Except for East Azarbaijan and Mazandaran, the incidence of symptomatic plants was more frequent in the northern (Alburz, Golestan and West Azarbaijan) or central (Qom and Tehran) provinces compared to the southern (Boushehr, Fars, Hormozgan, Isfahan, Kerman, Khuzestan and Sistan and Baluchestan) and western (Hamedan and Kermanshah) provinces of Iran. (Fig. 1). There were differences in the relative incidence of tobamovirus infection among the horticultural crops tested. The overall picture showed that tobamoviruses were distributed mostly on solanaceous crops (with an average incidence of $12.3 \%$ ) through the sampled regions compared to cucurbitaceous plants (with an average incidence rate of $8.1 \%$ ) with the few exceptions of the Larestan, Zabul, Qazvin, Jiroft, Dezful and 


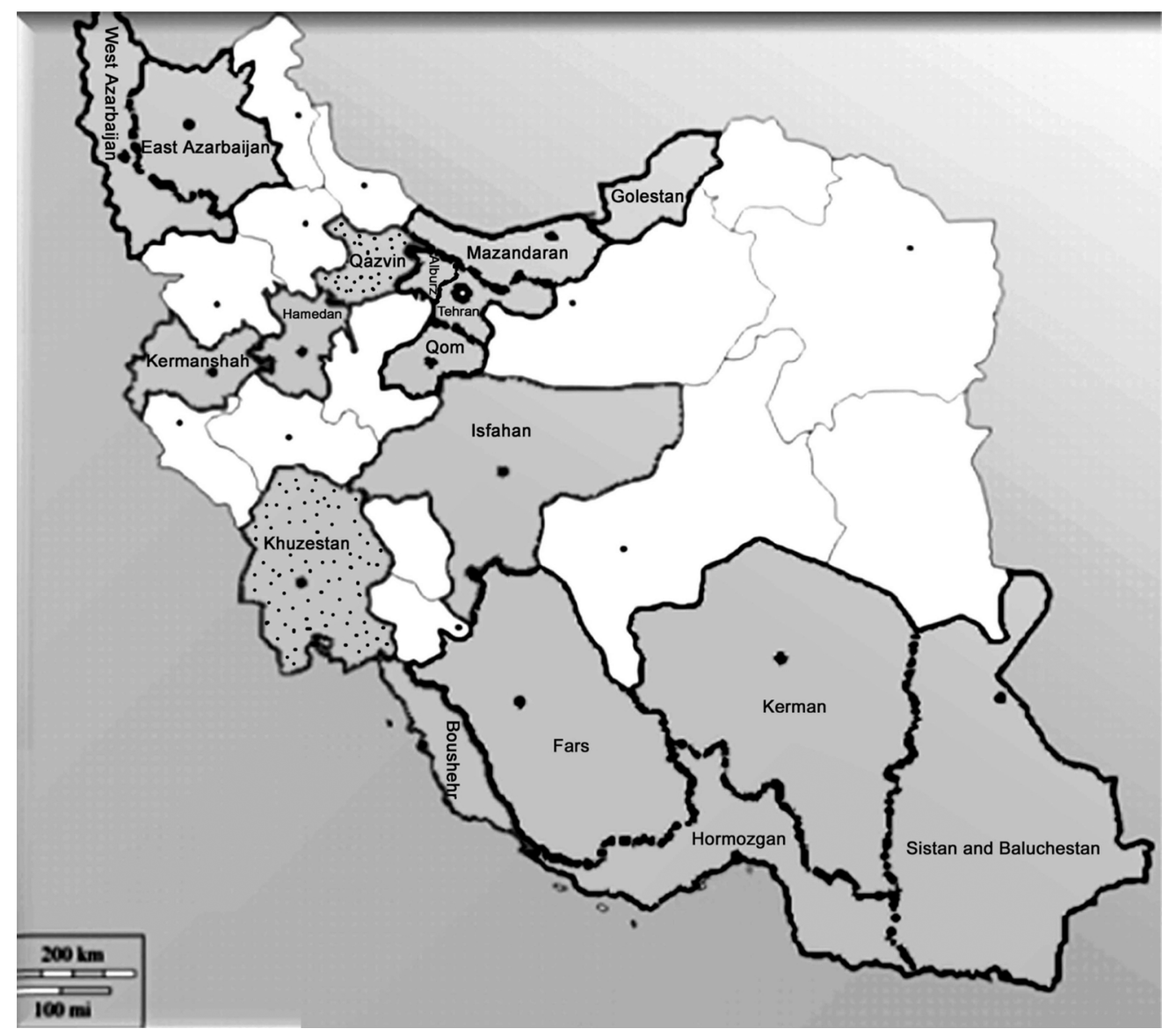

Fig. 1. Map of Iran showing the location of 17 provinces (shaded) where field-grown horticultural crops were surveyed for tobamovirus infection during the 2009 to 2010 growing seasons. Two provinces in which tobamovirus infection was not detected are shown spotted in the map.

Minab regions, where no virus was detected in any solanaceous samples tested (Table 1). Tobamovirus infection rates in crop samples showing symptoms, in decreasing order, were tomato $(16.9 \%)$, eggplant $(14.2 \%)$, watermelon $(12.0 \%)$, zucchini $(11.0 \%)$, pepper $(9.7 \%)$, potato $(8.2 \%)$, pumpkin $(6.9 \%)$, cabbage $(6.0 \%)$, bean $(5 \%)$, and cucumber $(2.6 \%)$ (Table 1). Tobamoviruses were not detected in radish. Symptomatic plants affected by tobamovirus infection were observed in most of the fields surveyed; however, the incidence varied according to the plant species and the geographical regions. Tobamovirus infection was characterized mainly by leaf and fruit mosaics. Plants infected with tobamoviruses showed severe stunting, malformation, yellow spotting on leaves, vein yellowing, mosaic patterns of light and dark green on the leaves and fruits, twisting of leaves, shoestring, interveinal and systemic chlorosis, leaf roll and necrosis.

Weed plants harboring tobamoviruses in horticultural crop fields. Of 107 weed leaf samples tested by the DASELISA, tobamoviruses were found in 12 samples. Twenty- six weed species belonging to 12 families were tested for the presence of tobamoviruses. There were seven weed species representing five families (Asteraceae, Chenopodiaceae, Convolvulaceae, Fabaceae and Malvaceae) in which tobamoviruses were detected in one or more locations (Table 2), attesting to the wide natural host range of these viruses. Tobamoviruses were detected serologically in two samples of C. album L., five samples of Chenopodium murale L., and one sample each of Cirsium arvensis L., Convolvulus arvensis L., Malva neglecta Wallr., Sonchus oleraceus L., and Trigonella persica L. (Table 2). Tobamoviruses were distributed mostly on weed species in the Chenopodiaceae family (23.3\%). None of the infected weeds showed virus symptoms. Infection of weed plants with tobamoviruses were confirmed following mechanical inoculation to $N$. tabacum cv. Samsun nn, N. tabacum cv. Virginia, N. tabacum cv. White Burley, and P. hybrida. Tobamoviruses caused necrotic local lesions, mild mosaic, vein clearing and leaf deformation on different inoculated indicator plant species. The presence of tobamoviruses in weed species also was verified by an RT-PCR test. 
Host range studies. The results of host range studies and the symptoms associated with virus infection on indicator plants were generally similar to those of earlier reports (Brunt et al., 1995; Chung et al., 2007; Holling and Huttinga, 1976; Jung et al., 2002), but with some differences (Table $3)$. The tobamovirus isolates, which were shown subsequently to be TMV isolates, were grouped into five pathological clusters (represented by isolates TA, TV, TM, G42 and PU1) based on differences in symptoms on host plants and nucleotide sequences of their CP genes. The representative isolates were detected in tomato from Alburz (TA), Tehran (TV) and East Azarbaijan (TM), eggplant from Golestan (G42) and pumpkin (PU1) from Fars province (Table 4). Of the 10 indicator plants tested (eight species from four families, including three varieties of tobacco), eight plants (six species) from three plant families developed symptoms after inoculation with the above Iranian TMV isolates. All five TMV isolates induced necrotic local lesions on inoculated leaves of faba bean and N. rustica (Table 3). Except for TMV-PU1, the other iso-

Table 4. Accession numbers, host and origin of reported TMV isolates used for phylogenetic comparison of coat protein gene sequence in this study

\begin{tabular}{ccccc}
\hline $\begin{array}{c}\text { Isolate or } \\
\text { Strain }\end{array}$ & $\begin{array}{c}\text { Accession } \\
\text { no. }\end{array}$ & Host & Origin & $\begin{array}{c}\text { Nt } \\
\text { identity }\end{array}$ \\
\hline TA & HQ593617 & Tomato & Iran & $94 \%$ \\
PU1 & HQ593618 & Pumpkin & Iran & $94 \%$ \\
TM & HQ593619 & Tomato & Iran & $94 \%$ \\
G42 & HQ593620 & Eggplant & Iran & $94 \%$ \\
TV & HQ593621 & Tomato & Iran & $94 \%$ \\
TMV-SoyIn & JQ895560 & Soybean & India & $99 \%$ \\
TMV-P & AY029262 & Petunia & Brazil & $96 \%$ \\
Chuxiong-1 & HE818417 & Tobacco & China & $95 \%$ \\
B935A & Z96945 & Faba bean & China & $99 \%$ \\
TMV-Egypt & AY686725 & Tomato & Egypt & $98 \%$ \\
Fulvum & AF546184 & Tobacco & Germany & $99 \%$ \\
Vulgare & AJ429078 & Tomato & Germany & $99 \%$ \\
K98 & AB669002 & Sweet pepper & Japan & $99 \%$ \\
699-07 & GQ340671 & Tobacco & Serbia & $98 \%$ \\
TMV-Pet & DQ981481 & Petunia & South Korea & $98 \%$ \\
IM & AB369276 & Impatiens & South Korea & $99 \%$ \\
Pet-TW & EF392659 & Petunia & Taiwan & $86 \%$ \\
TMV-pepper & AY633749 & Chili pepper & Thailand & $98 \%$ \\
TMV-Pet7 & GQ370523 & Petunia & U.S.A & $99 \%$ \\
OhioV & FR878069 & Petunia & U.S.A & $87 \%$ \\
Vulgare & DQ211985 & Canavalia & Venezuela & $99 \%$ \\
TMV-U1 & V01408 & Tobacco & Germany & $100 \%$ \\
ORSV & AB693990 & Orchid & Indonesia & - \\
\hline
\end{tabular}

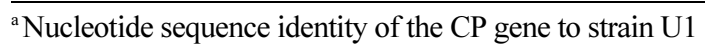

${ }^{\mathrm{b}}$ Odontoglossum ringspot virus (ORSV), a member of the genus Tobamovirus, which was used as an out-group species. lates were not infective in cucumber and cowpea cv. Mashhad plants (Table 3). Infections of cucumber with the PU1 isolate remained symptomless. This isolate elicited interveinal chlorosis in cowpea. Infection of cucumber with the PU1 isolate was confirmed by using RT-PCR and by mechanical inoculation onto other indicator plants (data not shown). TMV-PU1 differed from other TMV isolates and known strains of TMV (TMV-U1) in producing leaf curling in C. quinoa, vein clearing in N. tabacum cv. Virginia and necrotic local lesion in $P$. hybrida. TMV-G42 showed similar responses in the ten indicator plants as TMV-U1.

The TMV isolates TM, TV and TA, all detected first in tomato, caused distinct symptoms on inoculated leaves of C. quinoa, N. tabacum cv. Samsun nn and tomato. While TMV-TM and TMV-U1 caused systemic mosaic symptoms in inoculated N. tabacum cv. Samsun nn, TMV-TV induced necrotic local lesion and TMV-TA induced leaf deformation in the same tobacco cultivar, in addition to systemic mosaic. TMV-TM was also distinct from other tomato isolates and TMV-U1 in not producing leaf curling in tomato but inducing necrotic local lesions in C. quinoa (Table 3).

RT-PCR and phylogenetic relationships based on nucleotide sequence analysis. To confirm the serological diagnoses, RT-PCR was done using samples from naturally infected crop plants (218 samples that positively reacted with the anti-tobamovirus antiserum in the ELISA test) and selected weed species (12 samples). Except for radish, infection of the different crop and weed samples with TMV was confirmed by RT-PCR and specific primers (Fig. 2 and data not shown). RT-PCR also was successful in detecting TMV in the inoculated indicator plants. A single DNA fragment of the expected size (694 bp) was obtained by RTPCR with species-specific primers when the infected samples were examined for TMV (Fig. 2B and data not shown). No PCR products were amplified from healthy plants.

Using semi-nested RT-PCR and species-specific primers for ToMV and TMGMV, we were able to ascertain the relative incidence of these two viruses in mixed infection with TMV in infected samples (Table 5). For this purpose, a total of sixty crop samples, for which infection with TMV was demonstrated first by RT-PCR, were tested by speciesspecific primers for the presence of ToMV or TMGMV. PCR products with the expected size of approximately 690 bp and $720 \mathrm{bp}$ were obtained for ToMV and TMGMV, respectively, in some TMV-infected samples (Figs. 2C and D). Of the 60 tested samples, mixed infections of TMV with ToMV were found in 27 samples (45\%) including cucumber, eggplant, pumpkin, tomato, watermelon and zucchini in Fars, Alburz, East and West Azarbaijan, Mazandaran, Golestan and Tehran provinces (Table 5). 


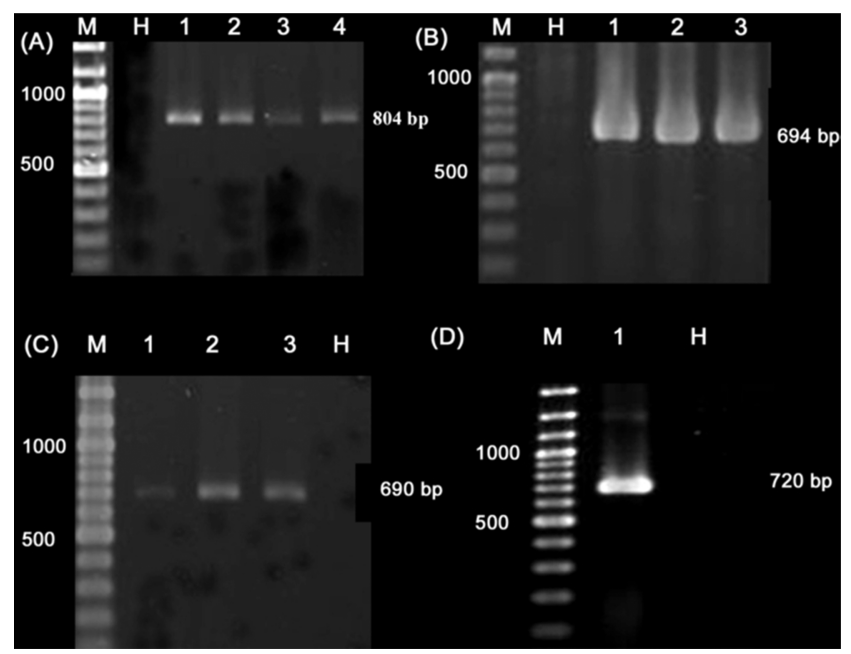

Fig. 2. Electrophoresis analysis of RT-PCR products. The products were obtained using $(\mathrm{A})$ the degenerate primer pair Tob-Uni 1/Tob-Uni 2 for detecting tobamoviruses in general, or speciesspecific primer pairs for detecting (B) Tobacco mosaic virus (TMV), (C) Tomato mosaic virus (ToMV), or (D) Tobacco mild green mosaic virus (TMGMV). (A), Lanes 1 to 4 represent amplified products from naturally infected bean, cabbage, pumpkin and radish samples, respectively; (B) and (C), Lanes 1 to 3 represent amplified products for naturally infected tomato, eggplant and cucumber samples, respectively; (D), Lane 1 represent amplified products for a naturally infected tomato sample. Lane M, 100-bp DNA ladder (Fermentas, Germany); Lane H, negative controls (PCR conducted using healthy plant material).
Mixed infections of TMV with either TMGMV or ToMV were detected only in four tomato samples $(6.6 \%)$ in Tehran and Alburuz provinces (Table 5). Plants with mixed infections showed more severe symptoms compared to those just singly infected with TMV.

A total number of the 116 crop samples with virus-like symptoms including bean (58 samples), cabbage (32 samples) and radish (26 samples) collected from Alburz, East Azarbaijan, Fars and Tehran provinces, which failed to react with polyclonal antisera for tobamoviruses in ELISA, were tested by degenerate primers (Tob-Uni 1/Uni 2) for the presence of other tobamoviruses. A PCR-amplified product of approximately $804 \mathrm{bp}$, corresponding to the CP gene of tobamoviruses plus sequences of $5^{\prime}$ and $3^{\prime}$ flanking regions, was obtained for all of these samples (Fig. 2A and data not shown). However, no PCR products were amplified when the same samples were tested for ToMV and TMGMV (data not shown), which may indicate the presence of yet other tobamoviruses.

The 480 nt sequences of the entire CP sequence in addition to 3 ' and 5' flanking sequences of the Iranian TMV isolates were obtained and deposited in the GenBank as accession numbers HQ593617, HQ593619 and HQ593621 for tomato isolates TA, TM and TV, HQ593620 for eggplant isolate G42 and HQ593618 for pumpkin isolate PU1, respectively (Table 4). A comparison of the nucleotide

Table 5. Relative incidence of ToMV and TMGMV present in TMV-infected crop samples ${ }^{\mathrm{a}}$

\begin{tabular}{|c|c|c|c|c|c|c|c|c|}
\hline \multirow{2}{*}{ Province } & \multirow{2}{*}{ Virus } & \multirow{2}{*}{ Samples ${ }^{\mathrm{b}}$} & \multicolumn{6}{|c|}{ Horticultural crops } \\
\hline & & & Tomato & Eggplant & Cucumber & Watermelon & Zucchini & Pumpkin \\
\hline \multirow{2}{*}{ Fars } & ToMV & 5 & 2 & 0 & 0 & ND & ND & ND \\
\hline & TMGMV & ND & ND & ND & ND & ND & ND & ND \\
\hline \multirow{2}{*}{ Alburz } & ToMV & 5 & 2 & 0 & 0 & 0 & 0 & 0 \\
\hline & TMGMV & 5 & 3 & 0 & 0 & 0 & 0 & 0 \\
\hline \multirow{2}{*}{ East Azarbaijan } & ToMV & 5 & 0 & 0 & 2 & 1 & ND & ND \\
\hline & TMGMV & ND & ND & ND & ND & ND & ND & ND \\
\hline \multirow{2}{*}{ Mazandaran } & ToMV & 5 & 1 & 1 & ND & ND & ND & ND \\
\hline & TMGMV & 5 & 0 & 0 & 0 & 0 & 0 & 0 \\
\hline \multirow{2}{*}{ Golestan } & ToMV & 5 & 2 & 2 & ND & ND & 1 & 1 \\
\hline & TMGMV & 5 & 0 & 0 & 0 & 0 & 0 & 0 \\
\hline \multirow{2}{*}{ West Azarbaijan } & ToMV & 5 & 2 & 0 & 0 & 3 & 0 & 0 \\
\hline & TMGMV & 5 & 0 & 0 & 0 & 0 & 0 & 0 \\
\hline \multirow{2}{*}{ Tehran } & ToMV & 5 & 3 & 2 & 0 & 0 & 1 & 1 \\
\hline & TMGMV & 5 & 2 & 0 & 0 & 0 & 0 & 0 \\
\hline \multirow{2}{*}{ Total } & ToMV & 60 & \multicolumn{6}{|c|}{27} \\
\hline & TMGMV & 00 & \multicolumn{6}{|c|}{5} \\
\hline
\end{tabular}

${ }^{a}$ Results obtained by semi-nested RT-PCR from 60 selected TMV-infected crop samples.

${ }^{\mathrm{b}}$ Number of vegetable samples infected with the specified tobamovirus. $\mathrm{ND}=$ not determined. 


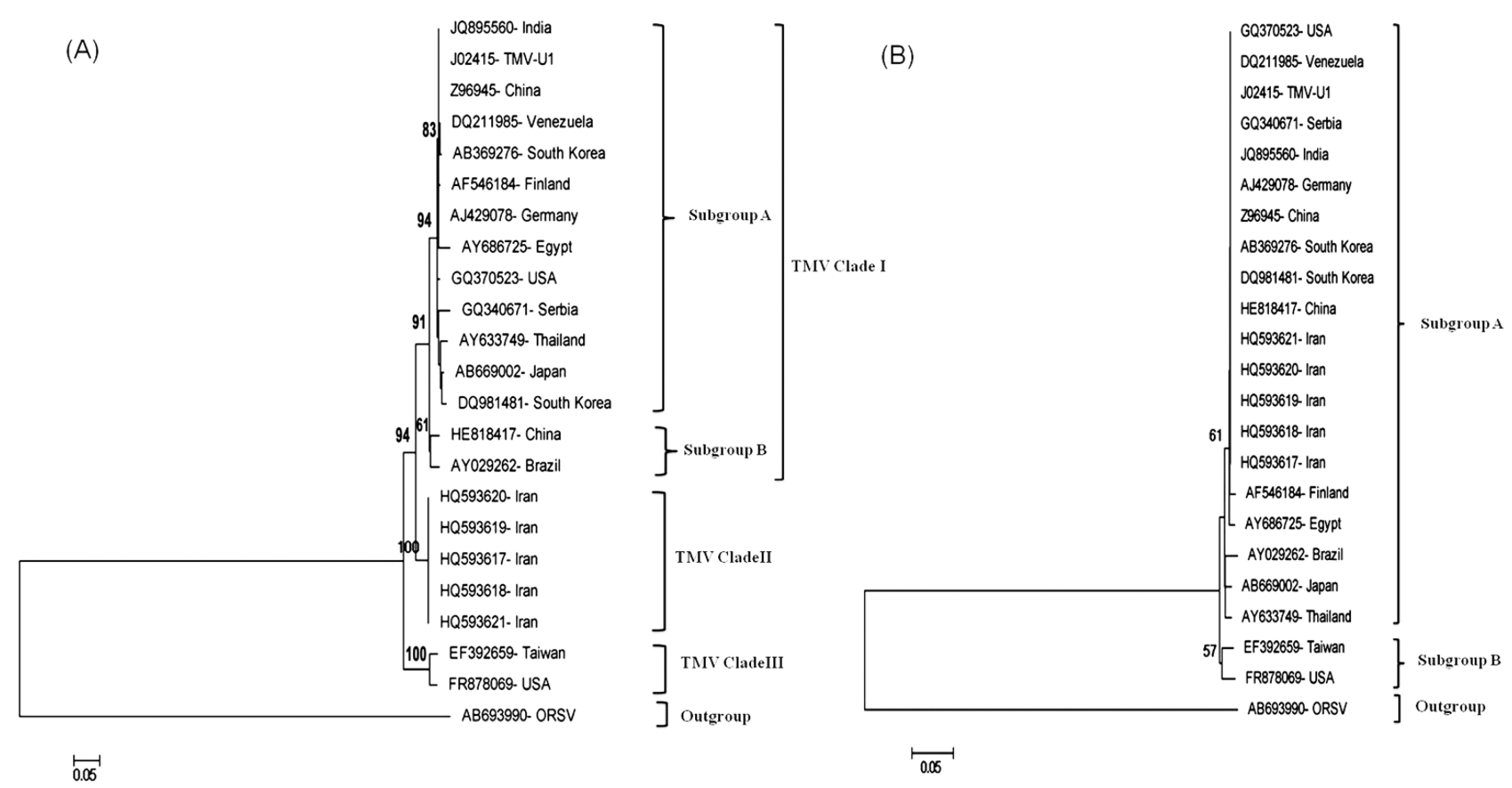

Fig. 3. Phylogenetic tree of TMV isolates constructed from the alignment of (A) 480 nucleotide and (B) 159 amino acid sequences of the $\mathrm{CP}$ gene of five TMV isolates from Iran, together with the homologous gene of TMV isolates from Brazil, China, Egypt, Germany, India, Japan, Serbia, South Korea, Taiwan, Thailand, USA and Venezuela (Table 4) using the neighbor-joining method based on 1000 replicates. Bootstrap percentages of clades are shown along internal branches of trees derived from bootstrap-resampled data sets. Branch lengths represent genetic distances. The tree was rooted with the $\mathrm{CP}$ of Odontoglossum ringspot virus (ORSV), a member of the genus Tobamovirus, which was used as an outgroup species (Table 4). Detailed information for each TMV isolate concerning the country where it was isolated and the accession number is found in the phylogenetic trees.

sequences for the CP gene of Iranian TMV isolates with those of other TMV isolates in the GenBank confirmed that these detected viruses were TMV. Nucleotide sequences of the complete ToMV and TMGMV CP genes that were obtained from RT-PCR positive samples also were deposited into the GenBank as accession numbers HQ593626 and HQ593622, respectively. Comparison of the nucleotide sequences of these two viruses with those of other isolates in the GenBank confirmed that these detected viruses were ToMV and TMGMV (data not shown). Thus, both ToMV and TMGMV were isolated from tomato in Tehran.

BLAST analysis of the TMV sequences of the CP gene disclosed complete identity (100\%) among the Iranian TMV isolates. The maximum and minimum nucleotide sequence identities of the entire CP gene ( $480 \mathrm{nt}$ ) between the Iranian isolates and those deposited previously in GenBank ranged from 93 to $94.5 \%$, whereas when the entire CP gene sequence plus $161 \mathrm{nt}$ flanking regions (641 nt) were compared they showed 90 to $94 \%$ sequence identity (data not shown). Phylogenetic analysis based on the nucleotide sequences of the CP gene resulted in classification of TMV isolates to three major clades with high bootstrap support in which isolates in clade I were divided into two subgroups (Fig. 3A). All of the Iranian TMV isolates clustered in clade
II, with 94\% similarity to TMV-U1 (the type TMV species present in clade I). Isolates Ohio V from USA together with Pet-TW from Taiwan were placed in clade III sharing 86$88 \%$ identity to TMV-U1. All the other TMV isolates (Table 4) were clustered in either the larger subgroup IA, sharing $96-100 \%$ nt sequence identities with isolate TMV$\mathrm{U} 1$ and comprising isolates from Asia, Africa, Europe and America, or the smaller subgroup IB, composed of only two isolates, one each from China and Brazil (Fig. 3A). The phylogenetic tree based on analysis of the $\mathrm{CP}$ amino acid sequences showed a different pattern compared to that of the nucleotide sequences of the $\mathrm{CP}$ genes (Fig. 3B). Here, the sequences of the amino acids of the $\mathrm{CP}$ gene formed two subgroups radiating from one large clade. Except for the Taiwan and one USA isolate (from clade III of the nucleotide sequence comparisons) in subgroup $\mathrm{B}$, the worldwide isolates were placed in subgroup $\mathrm{A}$, with the highest amino acid identity of $99 \%$ to the isolate TMV-U1. The amino acid sequence identity of the complete CP (159 aa) of the Iranian TMV isolates compared to TMV-U1 and other isolates ranged from 99 to $100 \%$. It should be noted that in these analyses we have not used all isolates from the GenBank that were labeled as TMV. This is because the CP of those isolates we did not use (accession numbers 
AF012927, AF103779, AF318214, AJ310339, and JN204355) were actually ToMV in sequence, as determined by sequence alignments, but the viruses were named TMV.

The pairwise nucleotide distances between isolates within a clade were $0.023,0.00$ and 0.029 for Clades I, II and III, respectively, whereas the distance between two clades was 0.149 . The distances of TMV isolates with respect to the ORSV sequence used as an outgroup were between 0.987 and 1.149. This may indicate that TMV could be classified into three genotypes. No correlation was observed between the genetic variation and the geographical origin from which the isolates were obtained. However, in comparing the genetic variation between the isolates in each clade, it seems there is a correlation between genetic variations and the species composing each genotype. Low nucleotide diversity $(<0.017)$ was observed within each subgroup indicating spatial genetic stability in different TMVs isolated throughout the world. Nucleotide diversity was also high and about 0.046 when any two clades were compared with each other. To estimate the extent of genetic differentiation, we measured the coefficient $F_{s t}$, which is also an estimate of gene flow (Weir and Hill, 2002). The $\mathrm{F}_{\mathrm{st}}$ values comparing clades I and II, as well as clade II and each subgroup (A and B) of clade I, were 0.914, 0.541, and 0.723 respectively, an indication of frequent gene flow. However $\mathrm{F}_{\mathrm{st}}$ values were lower than 0.312 between two the subgroups in clade I. The $\mathrm{F}_{\text {st }}$ values were lower than 0.1 between Asian and American or between European and either Asian or American isolates, indicating a low intercontinental gene flow between TMV isolates. The ratio of $d \mathrm{~N} / d \mathrm{~S}$ was $<1$ for CP genomic region of the Iranian TMV isolates, providing evidence of negative selection in this gene. The three statistic tests, Tajima D, Fu and Li's, were significantly negative $(P<0.05)$, suggesting negative or purifying selection.

\section{Discussion}

In recent years, there have been reports of increasing importance of virus diseases in horticultural crops in Iran (Bananej et al., 2006; Bananej and Vahdat, 2008; Dizadji and Shahraeen, 2009; Massumi et al., 2007; Pourrahim et al., 2007; Soleimani et al., 2011). In these earlier studies, the distribution and incidence of viruses infecting horticultural crops were studied by serological methods, but in none of these cases was TMV studied. Although the presence of TMV has been reported in tomato, tobacco and soybean from Iran (Golnaraghi et al., 2004; Khateri et al., 2008; Massumi et al., 2009), the distribution and incidence of this virus in different horticultural crops was not reported so for. Precise identification of TMV and knowledge about its distribution, genetic variation and alternative host sources in such crops will allow farm advisors and growers to make better management decisions. To achieve this, in the present study we sought to determine the incidence and distribution of TMV on economically important crops in the major horticultural crop-producing areas in 17 provinces throughout Iran. Natural weed hosts of TMV and the genetic variation of TMV also were investigated.

Our results showed that $11.3 \%$ of the total samples assessed from different horticultural crops were infected with TMV. This incidence, which is limited to the field plants showing symptoms, can be considered low if compared with that of other countries. For example, the incidence of TMV in pepper fields in Turkey, neighboring the northeastern region of Iran, was found to be $21.5 \%$ (ArliSokmen et al., 2005). The infection of horticultural crops by TMV was not equally distributed in Iran, since it ranged from a total absence in some provinces (Khuzestan and Qazvin) to a maximum of $43 \%$ in another (Golestan). Widespread prevalence of TMV in most crop-growing areas of Iran would implicate its major impact on crop production throughout the country. To our knowledge, this is the first report on the occurrence of TMV in bean, cabbage, cucumber, pepper, potato, pumpkin, watermelon and zucchini in Iran based on biological reactions, ELISA and RT-PCR. There was a clear-cut correlation between TMV incidence, geographical distribution and the type of vegetable hosts. Although TMV is not considered an economically important bean virus and is not common in bean fields in Iran, we detected TMV infected bean plants in Golestan (Table 1), which may reflect a very high inoculum in this province. Results of our study showed that TMV is present throughout the country, but a particularly extensive spread was recorded in Golestan $(43 \%)$ and West Azarbaijan (18.7\%) provinces (northern regions of Iran), where most of the national tobacco production is concentrated. Previously, TMV had been reported from different cultivars of tobacco with an incidence rate of $28.6 \%$ in these regions (Khateri et al., 2008). The relatively high incidence and prevalence of TMV may be related to the presence of tobacco fields near horticultural crops in these provinces. However, this relationship has yet to be confirmed. In the central provinces (Alburz, Qom and Tehran), TMV was detected in $18.8 \%$ of the total tested samples. TMV infection was confined to the fields with a history of solanaceous plant production in these regions. It is possible that failure to detect and subsequently eradicate TMV from these farms has led to its persistence in these areas. The virus can survive for many years in dead, dried plant material, which makes it difficult to inactivate (Broadbent, 1965). Plants that remain in the soil may harbor mechanically transmitted virus and act as a source of infection for the next crops, especially where the susceptible crops are grown 
in the same fields yearly (Hu et al., 1994; Lewandowski et al., 2010).

The results of ELISA tests showed the presence of TMV in various weed species distributed in the surveyed vegetable fields (Table 2). TMV was serologically detected previously in C. murale L. and Chrozophora hierosolymitana from some tomato cultivations in southern regions of Iran (Massumi et al., 2009). However, the natural occurrence of TMV on C. album L, Cirsium arvensis L, Convolvulus arvensis L, $M$. neglecta Wallr, S. oleraceus L, and T. persica $\mathrm{L}$, based on host range, ELISA, and PCR, is reported for the first time in this study. TMV overwinters in a number of weeds (Shiel and Castello, 1985; Arli-Sokmen et al., 2005). Primary infection of horticultural crops from overwintering sources of the virus can be a contributing factor in the increasing virus incidence in different plantations. Having knowledge of weed reservoirs of TMV is essential for understanding the virus epidemiology and must be understood for successful control through sanitation practices. In our survey, most weed species found to be infected with TMV were symptomless. Previous research also has shown that many TMV-infected herbaceous weed hosts often do not display foliar symptoms (Shiel and Castello, 1985). Nonetheless, further studies comprising more sampling of weed with regard to the symptom status are necessary to improve our knowledge of virus spread in the region.

The number of solanaceous plants shown to be infected with TMV was relatively high compared to collected cucurbit plant species (Table 1). Solanaceous crops incur the most significant losses from TMV-induced disease (Hollings and Huttinga, 1976). TMV is seed-borne mostly in solanaceous crops and they may spread during transplanting and harvesting after primary infections via infected seeds. Some growers in Iran use their own non-certified seed produced locally and this may contribute to the spread of TMV in these crops. It is noteworthy that TMV, a virus hitherto unreported from cucurbit plants in Iran, prevailed in having high rates of incidence in two cucurbit species (watermelon and zucchini) in the surveyed regions.

Due to the similarity of symptoms induced by TMV with those induced by other tobamoviruses and the possibility of mixed infection of TMV with other tobamoviruses, we tested the TMV infected samples for the presence of TMGMV and ToMV (other tobamoviruses in subgroup I). Mixed infections of tomato with TMV and TMGMV were only observed in Tehran and Alburz. We have previously reported the occurrence of TMGMV in tomato in Tehran (Alishiri et al., 2011). The low incidence of this virus in Iran may suggest that it is a new pathogen in the country. Mixed infection of tomato, eggplant, cucumber, watermelon, zucchini and pumpkin with TMV and ToMV were encountered at Fars, Alburz, East and West Azarbaijan, Mazandaran,
Golestan and Tehran as attested by the data in Table 5 . Although, mixed infection of solanaceous crops with TMV and ToMV was reported previously in some parts of Iran (Aghamohammadi et al., 2011; Ahoonmanesh et al., 1992; Massumi et al., 2009), the data shown in this study represent the first report on the occurrence of ToMV and its coinfection with TMV in cucurbit plants including cucumber, pumpkin, watermelon and zucchini in Iran. The higher incidence of TMV and ToMV mixed infections compare to TMV and TMGMV mixed infections may indicate that they arose from a common ancestor before colonizing and spreading in Iran.

The host ranges of different TMV isolates collected from different hosts and regions were similar to what has been previously reported for TMV (Chung et al., 2007; Jung et al., 2002; Novikov et al., 2000), but considerable differences were found in the symptoms induced by each TMV isolate on the indicator plants. The five TMV pathology clusters studied in this research showed obvious differences in the symptom development on C. quinoa, cowpea cv. Mashhad, N. tabacum cv. White Burley and tomato. Differences in symptom development on $C$. quinoa, cowpea and N. tabacum cv. Virginia observed after inoculation with TMV-PU1 (pumpkin isolate) distinguished this isolate from the tomato infecting isolates. TMV-PU1 also was differentiated from other isolates by infecting cucumber plants (Table 3). By contrast, the results also showed that three tomato-infecting TMV isolates (TA, TV and TM), collected from different geographical regions, differed in symptom developments on the indicator plants. Taken together, the data obtained by bioassay suggest clear differences between Iranian isolates of TMV which may be due to the genetic variation among TMV strains present in different hosts and geographical locations and/or climate regions in Iran. Many different strains of TMV are present in nature, which are different in biological properties (Van Regenmortel, 1986). It has been shown that sequences in TMV CP are often responsible for differences in symptom development (Culver, 2002). The work of Aldaoud et al. (1989) has shown that TMV isolates are differentially selected by different plant species and selective pressure plays an important role in TMV genetic divergence. This is in contrast to the results obtained by phylogenetic analysis of Iranian isolates that showed low genetic variations in the $\mathrm{CP}$ gene nucleotide sequence, which suggests the negative selection acting on this gene. We found significant evidence for negative selection in the CP gene of a large subset of TMV isolates. In our data set, most parts of the ORF were determined to be under negative selection for the Iranian isolates. For most of these TMV genes, the $d \mathrm{~N} / d \mathrm{~S}$ ratio was smaller than 1.0 , which was consistent with the negative selection against protein changes. The negative selection in the $\mathrm{CP}$ gene would result 
in a higher protein tolerance against mutation and pressure selection. This may indicate that TMV CP is not flexible in the interaction with other proteins or has little specific interaction with the host or potential vectors. This result also supports the hypothesis that the $\mathrm{CP}$ was undergoing intensive evolution. Previously, negative selection was reported for the worldwide ToMV isolates on the basis of the CP gene sequence (Rangel et al., 2011). However, the results indicated a low genetic diversity between isolates within clades and high diversity between the three clades, suggesting effects of selection under different selection pressures. This finding may suggest that different TMV isolates that are best fitted in a given geographical location/ climate have increased in the population. This conclusion has been demonstrated for resistance-breaking isolates of ToMV that overcome the resistance of the $T m-1$ gene (Pelham et al., 1970).

Phylogenetic analysis resulted in a tree with three main parts. Iranian TMV-crop isolates obtained from eggplant, pumpkin and tomato, respectively were all clustered together in a distinct branch. No branching pattern based on differences in the host source was found among the TMV-crop isolates studied. All TMV isolates which are distributed in Asia, Africa, Europe and America were located in one clade which could be divided into two subgroups with a branching pattern specific to geographical distribution. These indicate no clear correlation between $\mathrm{CP}$ sequence variation and the geographical origins of the virus isolates, in contrast to the results obtained by Jung et al. (2002) who differentiated TMV-potato isolates on the basis of geographical locations/climates. Previous studies elucidated that TMV isolates may be altered by different temperatures (Jones and Dawson, 1978) or in different plant species (Yarwood, 1979). Our results showed that the diversity values are high between the three clades, which may suggest that the populations in each clade could be derived from a single origin. Considering the low number of isolates in clade II, it is possible that the viruses in clade II might represent introductions that have occurred recently. The observed low diversity and the determination that TMV isolates from different host species had the same predominant genotype suggest that host species do not contribute to differentiation of the virus population, as observed with other plant viruses (Garcia-Arenal et al., 2001). No correlation was observed between the genetic distance and the geographical origin or the host species from which the isolates were obtained.

Clade III was composed of TMV isolates from the USA and Taiwan, whereas Clade I was composed of isolates from USA and the rest of the world. Low genetic variation among geographically distant isolates also has been reported for other tobamoviruses (Fraile et al., 1996; RodriguezCerezo et al., 1989). The apparent absence of a natural vector might have prevented population changes and might account for the low genetic diversity observed. However, the possibility of subjection to host selection may not be conceivable for the Iranian isolates, since they were collected from different hosts (Table 2).

In this study, the statistical test $\mathrm{F}_{\text {st }}$ was used to assess genetic differentiation and the gene flow level between clades and subgroups. Interestingly, in most cases where Iranian isolates were compared against other geographical groups in subgroup A (for example, Europe and the Americas) the $F_{\text {st }}$ values were low but when pairwise comparisons were repeated using the Iranian isolates in clade II and isolates in other clades, the $\mathrm{F}_{\text {st }}$ values were high. This result, together with the phylogenetic analyses, demonstrates the occurrence of gene flow from other isolates to the Iranian population. Our conclusions are consistent with previous research on ToMV (Rangel et al., 2011) showing that limited gene flow occurred between subpopulations from different geographical locations/climates. Overall, a high degree of differentiation was noted between three clades. It may suggest that TMV populations in each clade went through frequent bottlenecks when colonizing new habitats and members of each founder group were from similar population sources. The $\mathrm{F}_{\mathrm{st}}$ values between the Iranian-Asian and Iranian-European isolates were 0.678 and 0.914 , respectively, indicating that most of the molecular diversity is distributed among these geographical groups.

In conclusion, TMV isolates grouped into three main clades or genotypes worldwide and in combination with the recent work of Rangel et al. (2011), our analysis reveals that high genetic stability of different TMV isolates could be favored by genetic shift after bottlenecks. The genetic structure of TMV populations in different horticultural crops has not been analyzed in other Asian countries and it is not known if the Iranian isolates are present in other countries. Nonetheless, to control TMV infection, sanitary measures should be implemented to minimize TMV dispersal through plant material between countries. These results might provide useful tools to study the interplay between the evolutionary and epidemiological processes acting on TMV population and could help us to design some efficient control strategies for TMV emergence.

\section{Acknowledgments}

This work was supported by the Plant Pathology Department of Islamic Azad University (Tehran). PP was supported by a grant from the Research Professorship Program through the National Research Foundation of Korea (NRF) funded by the Ministry of Education, Science and Technology (MOEHRD-KRF-2012-0007187) and by Grant No. RDA-PJ007984042013 from the Next Generation BioGreen 
21 Program of Rural Development Administration of the Rep. of Korea.

\section{References}

Adkins, S., Kamenova, I., Achor, D. and Lewandowski, D. J. 2003. Biological and molecular characterization of a novel tobamovirus with a unique host range. Plant Dis. 87:11901196.

Aldaoud, R., Dawson, W. O. and Jones, G. E. 1989. Rapid, random evolution of the genetic structure of replicating tobacco mosaic virus populations. Intervirology 30:227-233.

Alexandre, M. A. V., Soares, R. M., Rivas, E. B., Duarte, L. M. L., Chagas, C. M., Saunal, H., Van Regenmortel, M. H. V. and Richtzehain, L. J. 2000. Characterization of a strain of Tobacco mosaic virus from Petunia. J. Phytopathol. 148:601-607.

Alishiri, A., Rakhshandehroo, F. and Zamanizadeh, H. R. 2011. First report of Tobacco mild green mosaic virus infecting tomato in Iran. New Dis. Rep. 23:30.

Aghamohammadi, V., Rakhshandehroo, F. and Shams-Bakhsh, M. 2011. First report of Tomato mosaic virus in eggplant in Iran. J. Plant Path. 93:S4.69.

Ahoonmanesh, A., Bahar, M. and Ghobadi, C. 1992. Tomato mosaic virus in Iran. Iran. J. Plant Pathol. 28:1-4.

Altschul, S. F., Madden, T. L., Schäffer, A. A., Zhang, J., Zhang, Z., Miller, W. and Lipman, D. J. 1997. Gapped BLAST and PSI-BLAST: a new generation of protein database search programs. Nucleic Acids Res. 25:3389-3402.

Alonso, E., Garcia-Luque, I., Avila-Rincon, M. J., Wicke, B., Serra, M. T. and Diaz-Ruiz, J. R. 1989. A tobamovirus causing heavy losses in protected pepper crops in Spain. J. Phytopathol. 125:67-76.

Antignus, Y., Wang, Y., Pearlsman, M., Lachman, O., Lavi, N. and Gal-on, A. 2001. Biological and molecular characterization of a new cucurbit-infecting Tobamovirus. Phytopathology 91:565-571.

Arli-Sokmen, M., Mennan, H., Sevik, M. A. and Ecevit, O. 2005. Occurrence of viruses in field-grown pepper crops and some of their reservoir weed hosts in Samsun, Turkey. Phytoparasitica 33:347-358.

Bananej, K., Desbiez, C., Wipf-Scheibel, A., Vahdat, A., KheyrPour, A., Ahoonmanesh, A. and Lecoq, H. 2006. First report of Cucurbit aphid-borne yellows virus in Iran causing yellows on four cucurbit crops. Plant Dis. 90:526.

Banane, K. and Vahdat, A. 2008. Identification, distribution and incidence of viruses in field-grown cucurbit crops of Iran. Phytopath. Medit. 47:247-257.

Broadbent, L. H. 1965. The epidemiology of tomato mosaic. Seed-transmission of TMV. Ann. Appl. Biol. 56:177-205.

Brunt, A. A., Crabtree, K., Dallwitz, M. J., Gibbs, A. J. and Watson, L. 1995. Viruses of plants: Description and lists from the VIDE database. CAB International, Wallingford, UK.

Channuntapipat, C., Sedgley, M. and Collins, G. 2001. Sequences of the cDNAs and genomic DNAs encoding the S1, S7, S8, and Sf alleles from almond, Prunus dulcis. Theor. Appl. Genet.
103:1115-1122.

Cherian, S. and Muniyapppa, V. 1998. ELISA based survey and host range of tomato mosaic tobamovirus. Ind. J. Virol. 14:6569.

Chitra, T. R., Prakash, H. S., Albrechtsen, S. E., Shetty, H. S. and Mathur, S. B. 2002. Indexing of leaf and seed samples of tomato and bell pepper for tobamoviruses. Ind. Phytopathol. 55:84-86.

Choi, S. K., Yoon, J. Y. and Chung, B. N. 2009. Genome analysis and characterization of a tobacco mosaic virus isolate infecting balsam (Impatiens balsamina). Arch. Virol. 154:881-885.

Chung, B. N., Kim, J. S., Cho, J. D., Cheong, S. R. and Jeong, M. I. 2007. Tobacco mosaic virus detected in vegetatively propagated petunia hybrid 'Surfinia'. Plant Pathol. J. 23:34-36.

Clark, M. F. and Adams, A. N. 1977. Characteristics of the microplate method of enzyme-linked immunosorbent assay for the detection of plant viruses. J. Gen. Virol. 34:475-483.

Culver, J. N. 2002. Tobacco mosaic virus assembly and disassembly: Determinants in pathogenicity and resistance. Annu. Rev. Phytopathol. 40:287-308.

Dizadji, A. and Shahraeen, N. 2009. Occurrence, distribution and seasonal changes of viruses infecting common bean in northwestern Iran. Arch. Phytopath. Plant Protec. 44:1647-1654.

F.A.O. 2009. F.A.O. Statistical Databases. Preliminary 2009 production data. http://faostat.fao.org/site/339/default.aspx.

Fraile, A., Malpica, J. M., Aranda, M. A., Rodriguez-Cerezo, E. and Garcia-Arenal, F. 1996. Genetic diversity in tobacco mild green mosaic tobamovirus infecting the wild plant Nicotiana glauca. Virology 223:148-155.

Fu, Y. X. and Li, W. H. 1993. Statistical tests of neutrality of mutations. Genetics 133:693-709.

Garcia-Arenal, F., Fraile, A. and Malpica, J. M. 2001. Variability and genetic structure of plant virus populations. Ann. Rev. Phytopathol. 39:157-186.

Goelet, P., Lomonossoff, G. P., Butler, P. J. G., Akam, M. E., Gait, M. J. and Karn, J. 1982. Nucleotide sequence of tobacco mosaic virus RNA. Proc. Natl. Acad. Sci. USA 9:5818-5822.

Golnaraghi, A. R., Shahraeen, N., Pourrahim, R., Farzadfar, Sh. and Ghasemi, A. 2004. Occurrence and relative incidence of viruses infecting soybeans in Iran. Plant Dis. 88:1069-1074.

Hollings, M. and Huttinga, H. 1976. Tomato mosaic virus. CMI/ AAB Descriptions of plant viruses, no. 156. Commonwealth Mycology Institute/Association for Applied Biology, Kew.

Hu, J. S., Ferreira, S., Xu, M. Q., Lu, M., Iha, M., Pflum, M. and Wang, M. 1994. Transmission, movement and inactivation of Cymbidium mosaic and Odontoglossum ringspot viruses. Plant Dis. 78:633-636.

Jones, G. E. and Dawson, W. O. 1978. Stability of mutations conferring temperature sensitivity on tobacco mosaic virus. Intervirology 9:149-155.

Jung, H. W., Yun, W. S., Hahm, Y. I. and Kim, K. H. 2002. Characterization of Tobacco mosaic virus isolated from potato showing yellow leaf mosaic and stunting symptoms in Korea. Plant Dis. 86:112-117.

Khateri, H., Moarrefzadeh, N., Mosahebi, G. and Koohi-Habibi, M. 2008. Virus diseases in the tobacco fields of Gilan and 
West Azarbaijan provinces of Iran. Comm. Appl. Biol. Sci. 73:307-310.

Kimura, M. 1980. A simple method for estimating evolutionary rate of base substitutions through comparative studies of nucleotide sequences. J. Mol. Evol. 16:111-120.

Kumar, S., Udaya Shankar, A. C., Nayaka, S. C., Lund, O. S. and Prakash, H. S. 2011. Detection of Tobacco mosaic virus and Tomato mosaic virus in pepper and tomato by multiplex RTPCR. Lett. Appl. Microbiol. 53:359-363.

Lartey, R. T., Voss, T. C. and Melcher, U. K. 1996. Tobamovirus evolution: gene overlaps, recombination, and taxonomic implications. Mol. Biol. Evol. 13:1327-1338.

Letschert, B., Adam, G., Lesemann, D. E., Willingmann, P. and Heinze, P. 2002. Detection and differentiation of serologically cross-reacting tobamoviruses of economical importance by RT-PCR and RT-PCR-RFLP. J. Virol. Method. 106:1-10.

Lewandowski, D. J., Hayes, A. J. and Adkins, S. 2010. Surprising results from a search for effective disinfectants for Tobacco mosaic virus contaminated tools. Plant Dis. 94:542-550.

Librado, P. and Rozas, J. 2009. DnaSP v5: A software for comprehensive analysis of DNA polymorphism data. Bioinformatics 25:1451-1452.

Massumi, H., Samei, A., Hosseini Pour, A., Shaabanian, M. and Rahimian, H. 2007. Occurrence, distribution, and relative incidence of seven viruses infecting greenhouse-grown cucurbits in Iran. Plant Dis. 91:159-163.

Massumi, H., Shaabanian, M., Hosseini Pour, A., Heydarnejad, J. and Rahimian, H. 2009. Incidence of viruses infecting tomato and their natural hosts in the southeast and central regions of Iran. Plant Dis. 93:67-72.

Moreira, S. R., Eiras, M., Chaves, A. L. R., Galleti, S. R. and Colariccio, A. 2003. Caracterização de uma nova estirpe do Tomato mosaic virus isolada de tomateiro no Estado de São Paulo. Fitopatol. Brasil. 28:602-607.

Nassar, E. A., El-Dougdoug, K. A., Osman, M. E., Dawoud, R. A. and Kinawy, A. H. 2012. Characterization and elimination of a TMV isolate infecting Chrysanthemum plants in Egypt. Int. J. Virol. 8:14-26.

Nei, M. and Kumar, S. 2000. Molecular Evolution and Phylogenetics. Oxford University Press, New York.

Novikov, V. K., Belenovich, E. V., Dobrov, E. N. and Zavriev, S. K. 2000. Kazakh strains of tobacco mosaic virus: two strains with potentially destabilizing amino acid substitutions in the coat protein. Physiol. Mol. Plant Path. 56:71-77.

Padgett, H. S. and Beachy, R. N. 1993. Analysis of a tobacco mosaic virus strain capable of overcoming $N$ gene-mediated resistance. Plant Cell 5:577-586.

Pearson, W. R. and Lipman, D. J. 1988. Improved tools for biological sequence comparison. Proc. Natl. Acad. Sci. USA 85: 2444-2448.

Pelham, J., Fletcher, J. T. and Hawkins, J. H. 1970. The establish- ment of a new strain of tobacco mosaic virus resulting from the use of resistant varieties of tomato. Ann. Appl Biol. 65: 293-297.

Pourrahim, R., Farzadfar, Sh., Golnaraghi, A. R. and Ahoonmanesh, A. 2007. Incidence and distribution of important viral pathogens in some Iranian potato fields. Plant Dis. 91:609-615.

Rangel, E. A., Alfaro-Fernandez, A., Font-San-Ambrosio, M. I., Luis-Arteaga, M. and Rubio, L. 2011. Genetic variability and evolutionary analyses of the coat protein gene of Tomato mosaic virus. Virus Genes 43:435-438.

Rodrıguez-Cerezo, E., Moya, A. and Garcı!a-Arenal, F. 1989. Variability and evolution of the plant RNA virus Pepper mild mottle virus. J. Virol. 63:2198-2203.

Saitou, N. and Nei, M. 1987. The neighbor-joining method: A new method for reconstructing phylogenetic trees. Mol. Biol. Evol. 4:406-425.

Shiel, P. J. and Castello, J. D. 1985. Detection of tobacco mosaic and tobacco ringspot viruses in herbaceous and woody plants near virus-infected white ash trees in central New York. Plant Dis. 69:791-795.

Soleimani, P., Mosahebi, G. and Koohi-Habibi, M. 2011. Identification of some viruses causing mosaic on lettuce and characterization of Lettuce mosaic virus from Tehran Province in Iran. Afric. J. Agric. Res. 6:3029-3035.

Tajima, F. 1989. Statistical method for testing the neutral mutation hypothesis by DNA polymorphism. Genetics 123:585-595.

Tamura, K. 1992. Estimation of the number of nucleotide substitutions when there are strong transition-transversion and $\mathrm{G}+\mathrm{C}-$ content biases. Mol. Biol. Evol. 9:678-687.

Tamura, K., Peterson, D., Peterson, N., Stecher, G., Nei, M. and Kumar, S. 2011. MEGA5: Molecular evolutionary genetics analysis using maximum likelihood, evolutionary distance, and maximum parsimony methods. Mol. Biol. Evol. 28:27312739.

Van Regenmortel, M. H. V. 1986. Tobacco mosaic virus. Antigenic structure. In: The Plant Viruses, Vol. 2. M. H. V. van Regenmortel and H. Fraenkel-Conrat, ed. Plenum Press, New York.

Wang, H., Culver, J. N. and Stubbs, G. 1997. Structure of Ribgrass mosaic virus at 2.9 A resolution: evolution and taxonomy of tobamoviruses. J. Mol. Biol. 269:769-779.

Weir, B. S. and Cockerham, C. C. 1984. Estimating F-statistics for the analysis of population structure. Evolution 38:1358-1370.

Weir, B. S. and Hill, W. G. 2002. Estimating F-statistics. Ann. Rev. Genet. 36:721-750.

Yarwood, C. E. 1979. Host passage effect with plant viruses. $A d v$. Virus Res. 25:169-190.

Zaitlin, M. 1999. Elucidation of the genome organization of tobacco mosaic virus. Philos. Trans. R Soc. Lond. B Biol. Sci. 354:587-591. 